\title{
ISOLASI DAN UJI AKTIVITAS DAYA HAMBAT EKSTRAK ETANOL BIJI PINANG (Areca catechu L.) TERHADAP BAKTERI PADA LIDAH
}

\author{
Meiriza Djohari ${ }^{1,}$ Wulandari Yulia Putri ${ }^{2}$, Erniza Pratiwi ${ }^{3}$ \\ ${ }^{1,2,3}$,Sekolah Tinggi Ilmu Farmasi Riau
}

Email Korespondensi : meirizadj@gmail.com

\begin{abstract}
ABSTRAK
Biji pinang (Areca catechu L.) merupakan bahan alam yang memiliki aktivitas antibakteri dalam mengobati gigi yang sakit, nafas yang tidak sedap dan dapat menghambat pembentukan karies gigi. Penelitian ini bertujuan untuk mengetahui jenis bakteri berdasarkan morfologi dan hasil uji identifikasi bakteri pada lidah serta mengetahui pengaruh daya hambat ekstrak etanol biji pinang (Areca catechu L.) terhadap bakteri pada lidah. Pengujian aktivitas antibakteri menggunakan metode difusi cakram dengan variasi konsentrasi 10\%, 20\% dan 30\%. Hasil skrining fitokimia ekstrak etanol biji pinang mengandung alkaloid, terpenoid dan flavonoid. Hasil yang diperoleh dari uji identifikasi berdasarkan warna bakteri yaitu Branhamella catarrhalis, Staphylococcus epidermidis dan Straphylococcus aureus. Ekstrak etanol biji pinang (Areca catechu L.) paling baik dalam menghambat pertumbuhan bakteri Staphylococcus epidermidis dan Staphylococcus aureus dibandingkan dengan Branhamella catarrhalis. Berdasarkan data statistik Two Way Anova terhadap diameter zona hambat menyatakan terdapat perbedaan antar kelompok konsentrasi 10\%, 20\% dan 30\% dan terdapat perbedaan signifikan aktivitas daya hambat bakteri Branhamella catarrhalis dibandingkan dengan bakteri Staphylococcus epidermidis dan Straphylococcus aureus dan tetapi tidak berbeda signifikan antara bakteri Staphylococcus epidermidis dan Straphylococcus aureus.
\end{abstract}

Kata Kunci : Antibakteri, Ekstrak, Biji Pinang, Lidah 


\title{
ISOLATION AND INHIBITION ACTIVITY OF ETHANOL EXTRACT OF BETEL NUT (ARECA CATECHU L.) TO BACTERIA OF THE TONGUE
}

\begin{abstract}
Betel nut (Areca catechu L.) is a natural material that has antibacterial activity in treating diseased on teeth, halitosis and can inhibit of dental caries. The objective of this research is type of bacteria based on morphology, the results of bacterial identification tests on the tongue and to determine the effect of the inhibitory power of betel nut ethanol extract (Areca catechu L.) to bacteria of the tongue. Antibacterial activity testing using disc diffusion method with various concentrations of 10\%, 20\% and $30 \%$. Secondary metabolite contents are alkaloid, terpenoid and flavonoid.The results obtained from the identification test based on the color of bacteria Branhamella catarrhalis, Staphylococcus epidermidis and Straphylococcus aureus. Ethanol extract of areca nut (Areca catechu L.) is better to inhibiting the growth of Staphylococcus epidermidis and Staphylococcus aureus compared to Branhamella catarrhalis. Based on Two Way Anova statistical data on inhibitory zone diameters, there were differences between the concentration groups of 10\%, 20\% and 30\% and there were significant differences in the inhibitory activity of Branhamella catarrhalis bacteria compared to Staphylococcus epidermidis and Straphylococcus aureus bacteria but not significantly different between Staphylococcus epidermidis and Straphylococcus aureus bacteria.
\end{abstract}

Keywords : Antibacterial, Extract, Betel nut, Tongue

\section{PENDAHULUAN}

Kesehatan gigi dan mulut sering bukan menjadi hal yang utama bagi sebagian orang, seperti diketahui gigi dan mulut merupakan jalan utama masuknya berbagai macam mikroorganisme ke dalam tubuh bersama makanan dan minuman, sehingga dapat merusak organ tubuh lainnya. Persentase penduduk yang mempunyai masalah gigi dan mulut berdasarkan Riset Kesehatan Dasar (RISKESDAS) Departemen Kesehatan Republik Indonesia tahun 2013 melaporkan bahwa penduduk yang mempunyai masalah gigi dan mulut terjadi peningkatan dari 23,2\% menjadi 25,9\% (Anonim, 2013).

Penyakit gigi dan mulut yang banyak diderita masyarakat di Indonesia yaitu penyakit priodontal dan karies gigi, sumber dari kedua penyakit tersebut akibat terabaikannya kebersihan gigi dan mulut, sehingga terbentuk lapisan tipis yang menempel erat di permukaan gigi serta mengandung kumpulan bakteri disebut plak (Spolsky, 2000). Salah satu bagian utama di rongga mulut adalah lidah. Permukaan lidah bisa menjadi tempat tinggal bagi bakteri patogen yang dapat memiliki pengaruh langsung dalam 
perkembangan karies gigi, halitosis oral (bau mulut) atau periodontitis (infeksi gusi serius). Lidah menjadi faktor penting dalam mempengaruhi tingkat kolonisasi bakteri pada permukaan gigi (Monea et al., 2014). Banyak bakteri yang terdapat di lidah terutama bagian lidah yang paling dekat dengan tenggorokan (Wangko, 2013) karena lebih sulit dibersihkan dibanding bagian rongga mulut yang lain.

Beberapa bakteri yang terdapat di rongga mulut yaitu Veillonella atypical, Fusobacterium nucleatum dan Porphyromonas gingivalis merupakan bakteri yang ditemukan di lidah. Bakteri yang terdapat di lidah dapat menyebabkan bau mulut yaitu Porphyromonas gingivalis, Fusobacterium, prevotella intermedia dan Capnocytophaga spp (Danser et al., 2003). Jenis lain yaitu Streptococcus family seperti Streptococcus mitis, Streptococcus

parasanguinis,Streptococcus salivarius dan Streptococcus australis (Aas et al., 2005).

Dalam menjaga kesehatan mulut dapat dilakukan dengan beberapa cara, salah satunya dengan cara berkumur (Shie, 2014). Dalam sejumlah besar obat kumur terapeutik dirancang untuk mengurangi populasi bakteri mulut (Taringan, 2012). Penggunaan obat kumur antiseptik kimiawi dalam jangka panjang bisa menyebabkan efek yang tidak diinginkan, misalnya hipersensitivitas, gangguan sekresi kelenjar ludah, merubah keseimbangan kehidupan bakteri flora normal rongga mulut dan lidah terasa terbakar (Yuliharsini, 2005).
Hasil penelitian ekstrak etanol biji pinang (Areca catechu L.) yang diformulasikan sebagai pasta gigi denga konsentrasi 4,5\% memiliki aktivitas antibakteri kuat yang menghasilkan diameter daya hambat untuk Streptococcus mutans sebesar 11,37 $\mathrm{mm}$ dan Staphylococcus aureus sebesar 20,03 mm (Afni dkk, 2015). Penelitian yang dilakukan Anggraeni (2002) mengenai ekstrak yang mengandung Se hasil bioekstraksi dengan Acetobacter saccharomyces menghasilkan zona hambat bening di sekitar cakram yang menunjukkan aktivitas dalam menghambat pertumbuhan bakteri Streptococcus mutans, diameter zona hambat ekstrak biji pinang terhadap Streptococcus mutans yaitu $0,18 \mathrm{~cm}$. Golongan metabolit sekunder yang terdapat di dalam infusa biji pinang (Areca catechu L.) antara lain flavonoid, tannin dan saponin. Infusa biji pinang (Areca catechu L.) memiliki aktivitas bakteriostatik terhadap Streptococcus mutans dengan konsentrasi hambat minimal sebesar $30 \%$ (Shie, 2014). Penelitian yang dilakukan oleh Pransiska (2017) mengenai pemberian infusa biji pinang (Areca catechu L.) dengan metode dilusi pada konsentrasi 10\%, 20\% dan $30 \%$ mampu memberikan pengaruh dalam mengurangi jumlah koloni bakteri pada lidah dengan nilai rata-rata selisih sebesar 81,6; 92,8 dan 111,4 pada mukosa rongga mulut berturutturut diperoleh nilai rata-rata selisih sebesar 41,2; 46,8 dan 61. Sedangkan penelitian tentang aktivitas ekstrak etanol biji pinang (Areca catachu L.) 
terhadap hasil isolat bakteri pada lidah belum ada sebelumnya.

Untuk mengatasinya dapat menggunakan obat tradisional salah satunya tanaman pinang. Tanaman pinang telah banyak dimanfaatkan masyarakat indonesia sejak zaman dahulu, khususnya bagian biji yang digunakan untuk campuran makan sirih, air rebusannya juga digunakan sebagai obat kumur yang diyakini berkhasiat untuk menguatkan gigi (Shie, 2014). Berdasarkan uraian diatas penulis tertarik untuk melakukan uji identifikasi dan melihat pengaruh daya antibakteri ekstrak etanol biji pinang (Areca catechu L.) terhadap pertumbuhan bakteri pada apusan lidah. Penelitian ini bertujuan untuk mengetahui jenis bakteri berdasarkan morfologi dan hasil uji identifikasi bakteri pada lidah serta mengetahui pengaruh daya hambat ekstrak etanol biji pinang (Areca catechu L.) terhadap bakteri pada lidah.

\section{METODE PENELITIAN}

\section{Waktu dan Tempat Penelitian}

Penelitian ini dilaksanakan pada bulan April-Juli 2018, bertempat di Laboratorium Farmasi Bahan Alam, Laboratorium Kesehatan Daerah Riau dan Laboratorium Biofarmasi Sekolah Tinggi Ilmu Farmasi Riau.

\section{Populasi dan Sampel}

Populasi pada penelitian ini adalah mahasiswa Program Studi S1 Semester VIII Sekolah Tinggi Ilmu Farmasi (STIFAR) Riau. Sampel penelitian adalah apusan lidah, dilakukan dengan mengambil langsung apusan lidah pada anggota populasi yang digunakan sebagai sampel sebanyak 5 orang mahasiswa dari keseluruhan mahasiswa Program Strata 1 Semester VIIIdengan kriteria:

1. Perempuan

2. Usia 20-22 tahun

3. Dalam kondisi sehat

4. Mahasiswa dengan kondisi gigi tidak berlubang tampak

5. Bersedia menjadi sampel

Alat

Autoklaf (GEA®), masker, oven listrik (Memmert $\left.{ }^{\circledR}\right)$, timbangan analitik digital (Shimadzu®), rotary evaporator, hot plate, inkubator (Memmert $\left.{ }^{\circledR}\right), \quad$ paper oksidase, latex agglutination, vortex (AS ONE®), mikro pipet (Nesco®), beker glass (Pyrex®), spektrofotometer UV-Vis (Ultra Violet-visible) .

\section{Bahan}

Biji pinang (Areca catechu L.), bakteri dari apusan lidah yang diambil dari mahasiswa Program Studi S1 Semester VIII Sekolah Tinggi Ilmu Farmasi (STIFAR) Riau, etanol 96\% (sudah didestilasi), media Nutrient Agar, media Endo Agar, Media karbohidrat/Gula (glukosa, maltosa, sukrosa), kit Staphaurex, $\mathrm{NaCl}$ fisiologis $\quad 0,9 \%, \quad$ Chlorhexidine gluconate mouthwash $0,2 \%$, dettol antiseptik .

\section{Pengambilan Sampel Pinang}

Bagian sampel yang digunakan adalah biji pinang (Areca catechu L.) segar yang bewarna kuning orange yang diambil di Desa Kota Baru Kecamatan Tapung Hilir Kabupaten Kampar.

\section{Identifikasi Sampel Pinang}

Identifikasi tanaman pinang (Areca catechu L.) dilakukan di 
Laboratorium Botani Jurusan Biologi Fakultas Matematika dan Ilmu Pengetahuan Alam (FMIPA) Universitas Riau.

\section{Pembuatan Ekstrak Etanol Biji Pinang}

Sebanyak $12 \mathrm{~kg}$ buah pinang yang telah diambil dikupas untuk memisahkan bagian kulit dengan bijinya. Biji buah pinang tersebut dilakukan perajangan dan dilakukan pengeringan sampel menggunakan oven selama 2 hari. Sampel yang telah kering dihaluskan dengan cara diblender kemudian di Ekstraksidengan cara maserasi atau perendaman dengan menggunakan etanol. Sampel yang telah dikeringkan sebanyak 1,050 $\mathrm{kg}$ dimasukkan ke dalalam botol gelap dan direndam dengan etanol, ditutup dan terlindung dari cahaya matahari selama 5 hari pada suhu ruangan sambil dilakukan pengadukan agar zat aktif terekstraksi sempurna. Setelah 5 hari hasil maserasi disaring dengan kertas saring lalu filtratnya dipindahkan ke wadah tertutup.Kemudian dilakukan pengulangan sebanyak tiga kali.Hasil maserasi yang diperoleh dipekatkan dengan alat rotary evaporator untuk memisahkan pelarut dari zat aktif sehingga diperoleh ektrak kental etanol biji pinang.

\section{Skrining Fitokimia Ekstrak}

Pemeriksaan fitokimia yang dilakukan meliputi pemeriksaan alkaloid, terpenoid, flavonoid, steroid dan saponin.

\section{Sterilisasi Alat dan Bahan}

Alat-alat terbuat dari gelas (tabung reaksi, Erlenmeyer, cawan Petri, vial) dicuci bersih dan dikeringkan. Selanjutnya dibungkus dengan kertas koran, disterilkan menggunakan oven pada suhu $160^{\circ} \mathrm{C}$ selama 2 jam. Tip mikropipet dan media Nutrient Agar disterilkan menggunakan autoklaf pada suhu $121^{\circ} \mathrm{C}$ tekanan 1,5 atm selama 15 menit. Pinset, jarum Ose dan spatel disterilkan dengan cara pemijaran diatas api spiritus selama beberapa detik (Pratiwi, 2008).

\section{Pengambilan Apusan Lidah}

Apusan diambil dari sampel secara aseptis dan semua peralatan serta media yang digunakan dalam keadaan steril. Apusan lidah diambil dengan cara mengusap apusan di lidah menggunakan cotton bud steril. Sebelum apusan diambil, masing masing responden diberi sarapan pagi yang sama setelah itu dipuasakan selama 2 jam. Apusan lidah diambil secara bergantian dengan menggunakan cotton bud sterilyang berbeda. Apusan yang telah diambil di lidah kemudian dilarutkan dengan $\mathrm{NaCl}$ fisiologis $0,9 \%$ $2 \mathrm{~mL}$ dalam vial, dihomogenkan dan dimasukkan ke dalam cawan Petri dengan metode tuang, setelah itu masukkan media Nutrient Agar sebanyak 15-20 mL ke dalam cawan Petri yang sudah berisi apusan lidah, kemudian campuran tersebut diratakan berlawanan arah jarum jam hingga tersebar merata. Diinkubasi selama 24 jam pada suhu $37^{\circ} \mathrm{C}$. Amati koloni bakteri.

\section{Pemurnian Bakteri}

Koloni yang tumbuh pada masing-masing media diambil menggunakan jarum Ose untuk dipindahkan ke media Nutrient Agar di dalam cawan Petri dengan metode gores 
selanjutnya diinkubasi selama 24 jam pada suhu $37^{\circ} \mathrm{C}$.

\section{Pengujian Aktivitas Antibakteri}

Pengujian aktivitas antibakteri dilakukan dengan menggunakan metode difusi. Suspensi bakteri dipipet sebanyak 0,3 mL dimasukkan ke dalam cawan Petri. Media Nutrient Agar dimasukkan ke dalam cawan Petri sebanyak 10-15 mL, kemudian diratakan dan biarkan mengeras. Kertas cakram steril ditetesi sebanyak $10 \mu \mathrm{l}$ ekstrak etanol biji pinang pada masingmasing konsentrasi yang telah diencerkan $(10 \%, 20 \%, 30 \%)$ dikering anginkan, kemudian diletakkan diatas media Nutrient Agar. Diinkubasi pada suhu $37^{\circ} \mathrm{C}$ selama 24 jam. Diameter hambat diukur menggunakan jangka sorong.

\section{Analisa Data}

Data yang diperoleh dari penelitian ini adalah hasil uji identifikasi bakteri lidah berdasarkan morfologi dan uji biokimianya dan perbedaan konsentrasi ekstrak etanol biji pinang (Areca catachu L.) dalam menghambat pertumbuhan bakteri yang paling sering muncul pada lidah. Data yang diperoleh disajikan dalam bentuk tabel, gambar dan kemudian di analisa dengan uji statistik Two Way ANOVA dan dilanjutkan dengan uji Tukey Post Hoc.

\section{HASIL DAN PEMBAHASAN \\ Skrining Fitokimia}

Proses ekstraksi sampel dilakukan secara maserasi. Filtrat yang diperoleh kemudian diuapkan dengan rotary evaporator sehingga menghasilkan ekstrak kental etanol sebanyak 138,45 g dengan randemen 13,18\%. Sebelum melakukan uji aktivitas antibakteri terlebih dahulu dilakukan skrining fitokimia terhadap sampel segar dan ekstrak etanol biji pinang Senyawa metabolit sekunder yang terdapat pada sampel segar dan ekstrak etanol biji pinang (Areca catechu L.) yaitu alkaloid, terpenoid dan

Tabel 1. Hasil Skrining Fitokimia Metabolit Sekunder Biji Segar dan Ekstrak Etanol Biji Pinang (Areca catechu L.)

\begin{tabular}{cccc}
\hline Sampel & $\begin{array}{c}\text { Senyawa } \\
\text { Metabolit }\end{array}$ & Hasil & Hasil Pengamatan \\
& Alkaloid & + & Endapan putih \\
& Terpen & + & Merah \\
Biji Segar & Flavonoid & + & Merah \\
& Saponin & - & Tidak terbentuk busa \\
& Steroid & - & Tidak berwarna biru \\
\hline \multirow{5}{*}{ Ekstrak Etanol } & Flkaloid & + & Endapan putih \\
Biji Pinang & Terpen & + & Merah \\
& Saponin & - & Tidak terbentuk busa \\
& Steroid & - & Tidak berwarna biru \\
\hline
\end{tabular}




\section{Isolasi Apusan Lidah}

Hasil isolasi bakteri yang diperoleh dari lima sampel apusan lidah berdasarkan perbedaan warna koloni bakteri didapatkan tiga jenis koloni diberi penandaan L (Lidah) penamaan sesuai dengan warna yang didapat dari penanaman pada media Nutrient Agar. Masing-masing warna koloni yaitu koloni putih $\left(\mathrm{L}_{1}\right)$, koloni krem $\left(\mathrm{L}_{2}\right)$ dan koloni kuning $\left(\mathrm{L}_{3}\right)$

\section{Identifikasi Bakteri}

Pewarnaan Gram yang telah dilakukan menunjukkan bahwa koloni putih $\left(\mathrm{L}_{1}\right)$ merupakan bakteri Gram negatif bentuk diplokokus, sedangkan koloni krem $\left(\mathrm{L}_{2}\right)$ dan kuning $\left(\mathrm{L}_{3}\right)$ merupakan bakteri Gram positif bentuk kokus.

Hasil Uji Oksidase untuk koloni putih $\left(\mathrm{L}_{1}\right)$ dan koloni krem $\left(\mathrm{L}_{2}\right)$ memberi hasil positif ditandai dengan terbentuknya warna biru violet pada paper oksidase warna ini terbentuk hanya selama 5 detik selanjutnya berubah menjadi biru akibat adanya oksidasi sedangkan koloni kuning $\left(\mathrm{L}_{3}\right)$ memberi hasil negatif ditandai dengan tidak terbentuknya warna biru violet pada paper oksidase setelah dogores bakteri menggunakan jarum Ose. Uji Oksidase berperan dalam mendeteksi enzim oksidase pada bakteri (Radji, 2011).

Uji katalase berperan dalam membedakan antara Staphylococcus dan
Streptococcus dalam menghasilkan enzim katalase hasil Uji Katalase koloni putih $\left(\mathrm{L}_{1}\right)$, koloni krem $\left(\mathrm{L}_{2}\right)$ dan kuning $\left(\mathrm{L}_{3}\right)$ memberi hasil positif yang ditandai dengan terbentuknya gelembung udara setelah penambahan reagen $\mathrm{H}_{2} \mathrm{O}_{2}$.

Pada koloni krem $\left(\mathrm{L}_{2}\right)$ dan kuning ( $\left.\mathrm{L}_{3}\right)$ dilakukan Tes Serologi menggunakan kit Staphaurex, dimana tes ini bertujuan untuk membedakan antara Staphylococcus aureus dengan Staphylococcus epidermidis dengan melihat hasil akhir berupa aglutinasi menunjukkan positif Staphylococcus aureus.

Isolat koloni putih $\left(\mathrm{L}_{1}\right)$ yang tergolong dalam bakteri Gram negatif kokus selanjutnya dilakukan pengujian Fermentasi Karbohidrat (uji gula) meliputi pengujian glukosa, maltosa dan laktosa. Dimana pengujian ini bertujuan untuk melihat kemampuan bakteri dalam menghancurkan gula dan menghasilkan asam organik yang berasal dari tiap-tiap jenis gula, yaitu 
glukosa, sukrosa, maltose, arabinosa, manitol dan inositol (Harti, 2015). Tabung yang berisi media karbohidrat yang telah disiapkan, diinokulasi dengan satu Ose biakan bakteri, amati perubahan warna media. Pada uji fermentasi karbohidrat yang dilakukan tidak terjadi pembentukan asam pada media glukosa, maltosa dan laktosa memberikan hasil negatif hal ini karena tidak berubahnya warna pada media pada tabung, hal ini menandakan bakteri tidak memilki kemampuan dalam melakukan fermentasi terhadap karbohidrat tersebut.

Tabel 2. Hasil Identifikasi Bakteri Lidah

\begin{tabular}{|c|c|c|c|c|c|c|c|c|}
\hline $\begin{array}{l}\text { Koloni } \\
\text { Bakter } \\
\quad \text { i }\end{array}$ & $\begin{array}{l}\text { Pewarnaan } \\
\text { Gram }\end{array}$ & $\begin{array}{c}\text { Tes } \\
\text { Katalas } \\
\text { e }\end{array}$ & $\begin{array}{c}\text { Tes } \\
\text { Oksid } \\
\text { ase }\end{array}$ & $\begin{array}{c}\text { Tes } \\
\text { Serolo } \\
\text { gi }\end{array}$ & $\begin{array}{l}\text { Tes } \\
\text { Slokosa }\end{array}$ & $\begin{array}{l}\text { Tes } \\
\text { Maltosa }\end{array}$ & $\begin{array}{c}\text { Tes } \\
\text { Sukros } \\
\text { a } \\
\end{array}$ & Kesimpulan \\
\hline $\begin{array}{c}\mathrm{L}_{1} \\
\text { (Putih } \\
\text { ) }\end{array}$ & $\begin{array}{c}\text { Diplokokus } \\
\text { Gram } \\
\text { Negatif }\end{array}$ & + & + & $*$ & - & - & - & $\begin{array}{c}\text { Branhamella } \\
\text { catarrhalis }\end{array}$ \\
\hline $\begin{array}{l}\mathrm{L}_{2} \\
(\mathrm{Kre} \\
\mathrm{m})\end{array}$ & $\begin{array}{l}\text { Kokus } \\
\text { Gram } \\
\text { Positif }\end{array}$ & + & + & - & * & $*$ & $*$ & $\begin{array}{c}\text { Staphylococc } \\
\text { us } \\
\text { epidermidis }\end{array}$ \\
\hline $\begin{array}{c}\mathrm{L}_{3} \\
\text { (Kuni } \\
\mathrm{ng})\end{array}$ & $\begin{array}{l}\text { Kokus } \\
\text { Gram } \\
\text { Positif }\end{array}$ & + & - & + & * & $*$ & $*$ & $\begin{array}{c}\text { Staphylococc } \\
\text { us aureus }\end{array}$ \\
\hline $\begin{array}{l}\text { Keteran } \\
+: \text { Hasil } \\
-\quad: \text { Has } \\
\quad: \text { Tid }\end{array}$ & $\begin{array}{l}\text { gan: } \\
\text { Positif } \\
1 \text { Negatif } \\
\text { k dilakukan }\end{array}$ & ngujia & & & \multirow{3}{*}{\multicolumn{4}{|c|}{$\begin{array}{l}\text { menunjukkan adanya aktivitas } \\
\text { penghambatan terhadap Branhamella } \\
\text { catarhallis, Staphylococcus epidermidis } \\
\text { dan Staphylococcus aureus. Hasil } \\
\text { penelitian menunjukkan bahwa kontrol } \\
\text { negatif tidak memberikan zona } \\
\text { hambatan. Hal ini membuktikan bahwa } \\
\text { respon daya hambat yang terjadi benar- } \\
\text { benar disebabkan oleh ekstrak etanol } \\
\text { biji pinang (Areca catechu L.) atau } \\
\text { senyawa sebagai komponen aktif dan } \\
\text { bukan dari pelarut yang digunakan }\end{array}$}} \\
\hline $\begin{array}{l}\text { Uji Al } \\
\text { Pinang }\end{array}$ & $\begin{array}{l}\text { vitas Eks } \\
\text { reca catec }\end{array}$ & $\begin{array}{l}\text { ak } E \\
\text { L.) }\end{array}$ & ol & & & & & \\
\hline $\begin{array}{l}\text { antibak } \\
\text { Areca } \\
\text { konsent } \\
\text { positif }\end{array}$ & $\begin{array}{l}\text { Hasil } \\
\text { eri ekstrak } \\
\text { catechu L } \\
\text { rasi } 10 \%, 20 \\
\text { Chlorl }\end{array}$ & $\begin{array}{c}\text { uji } \\
\text { etanol b } \\
\text { deng } \\
\text { \%, } 30 \% \\
\text { ksidin }\end{array}$ & $\begin{array}{r}\text { aktivi } \\
\text { iji pinc } \\
\text { n vari } \\
\text { lan kon } \\
0,\end{array}$ & & & & & \\
\hline
\end{tabular}
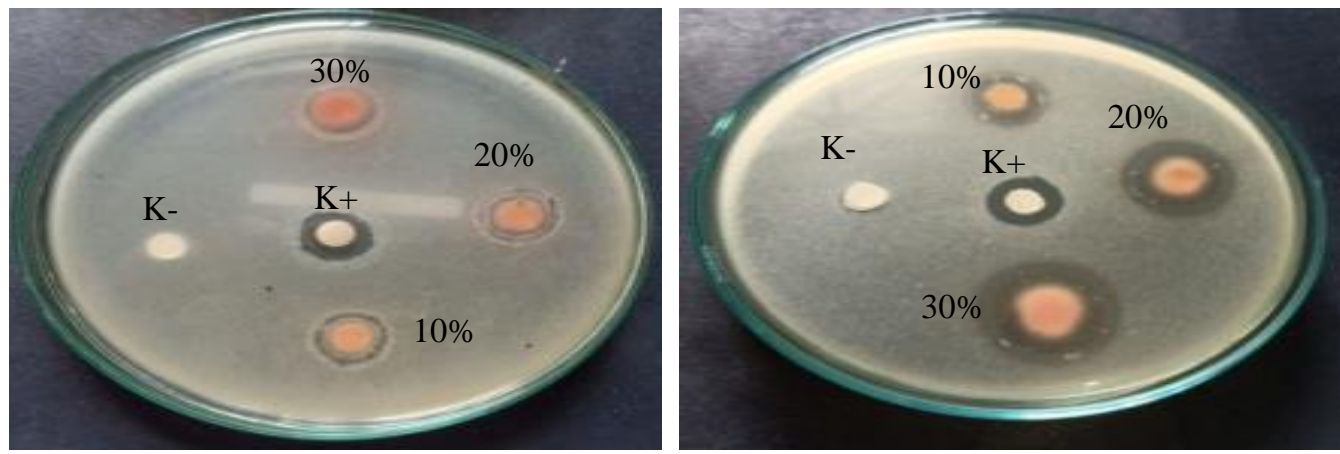
A

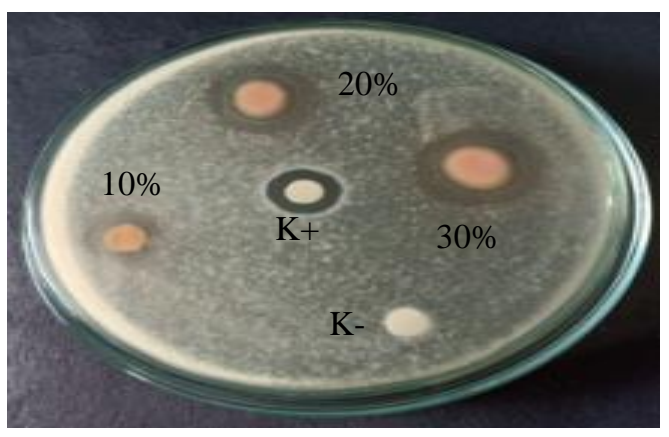

Keterangan:

A : Bakteri Branhamella catarrhalis

B : Bakteri Staphylococcus epidermidis

C : Bakteri Staphylococcus aureus

Nazri et al (2011) mengklasifikasikan diameter hambat yang beraktivitas kuat $15-20 \mathrm{~mm}$, diameter zona hambat yang beraktivitas sedang 10-14 $\mathrm{mm}$ dan diameter zona hambat yang beraktivitas lemah $<9 \mathrm{~mm}$. Jika dilihat dari rata-rata diameter zona hambat pada bakteri Branhamella catarrhalis maka dikaitkan dengan diameter zona hambatnya pada ekstrak etanol biji pinang (Areca catechu L.) dengan konsentrasi 10\%, 20\% dan 30\% berturut-turut diperoleh nilai rata-rata diameter zona hambat $8,87 \mathrm{~mm}, 10,33$ $\mathrm{mm}$ dan $11,67 \mathrm{~mm}$ termasuk pada kategori lemah sampai sedang. Pada bakteri Staphylococcus epidermidis dengan konsentrasi 10\%, 20\% dan 30\% berturut-turut diperoleh nilai rata-rata
B

diameter zona hambat $13,30 \mathrm{~mm}, 16,10$ $\mathrm{mm}$ dan 18,27 $\mathrm{mm}$ termasuk pada kategori sedang sampai kuat. Pada bakteri Staphylococcus aureus dengan konsentrasi 10\%, 20\% dan 30\% berturut-tururt diperoleh nilai rata-rata diameter zona hambat $12,07 \mathrm{~mm}, 15,10$ $\mathrm{mm}$ dan $16,90 \mathrm{~mm}$ termasuk pada kategori sedang sampai kuat. Sedangkan jika dilihat rata-rata diameter zona hambat pada bakteri Branhamella catarrhalis, Staphylococcus epidermidis dan Staphylococcus aureus maka dikaitkan dengan diameter zona hambat pada kontrol positif berturut-turut $12,47 \mathrm{~mm}$, $12,83 \mathrm{~mm}$ dan $12,50 \mathrm{~mm}$ termasuk pada kategori sedang.

Tabel 3. Hasil Uji Aktivitas Ekstrak Etanol Biji Pinang (Areca catechu L.)

\begin{tabular}{ccccccc}
\hline \multirow{2}{*}{ Bakteri uji } & Konsentrasi b/v\% & \multicolumn{4}{c}{ Diameter Daerah Hambat $(\mathbf{m m})$} & \multirow{2}{*}{ Rata-rata } \\
\cline { 2 - 6 } & & $\mathbf{1}$ & $\mathbf{2}$ & $\mathbf{3}$ & \\
\cline { 2 - 6 } & $\mathrm{K}-$ & 6 & 6 & 6 & 6,00 \\
\cline { 2 - 6 } Branhamella catarrhalis & $\mathrm{K}+$ & 11,9 & 12,6 & 12,9 & 12,47 \\
\cline { 2 - 6 } & $10 \%$ & 8,4 & 9,8 & 8,4 & 8,87 \\
\cline { 2 - 6 } & $20 \%$ & 10 & 11,4 & 9,6 & 10,33 \\
\hline Staphylococcus & $30 \%$ & 11,9 & 11,9 & 11,2 & 11,67 \\
\hline & $\mathrm{K}-$ & 6 & 6 & 6 & 6,00 \\
\hline
\end{tabular}




\begin{tabular}{cccccc}
\hline \multirow{2}{*}{ epidermidis } & $\mathrm{K}+$ & 12,3 & 14,2 & 12 & 12,83 \\
\cline { 2 - 6 } & $10 \%$ & 14,5 & 13,5 & 11,9 & 13,30 \\
\cline { 2 - 6 } & $20 \%$ & 20,9 & 14,7 & 12,7 & 16,10 \\
\cline { 2 - 6 } & $30 \%$ & 22 & 19 & 13,8 & 18,2 \\
& $\mathrm{~K}+$ & 6 & 6 & 6 & 6,00 \\
\cline { 2 - 7 } Staphylococcus aureus & $\mathrm{K}-$ & 12,2 & 13,1 & 12,2 & 12,50 \\
\cline { 2 - 7 } & $10 \%$ & 9,8 & 13,8 & 12,6 & 12,07 \\
\cline { 2 - 7 } & $20 \%$ & 12,4 & 17,2 & 15,7 & 15,10 \\
\cline { 2 - 7 } & $30 \%$ & 13,3 & 18,6 & 18,8 & \multicolumn{2}{c}{16,9} \\
\hline
\end{tabular}

\section{Keterangan:}

Diameter cakram $6 \mathrm{~mm}$

Kontrol positif : Chlorhexidine gluconate moutwash $0,2 \%$

Kontrol negatif : Pelarut ekstrak (etanol 96\% sudah didestilasi)

Berdasarkan hasil uji Two Way ANOVA pengujian aktivitas ekstrak etanol biji pinang (Areca catechu L.), berdasarkan variabel bakteri uji dan konsentrasi diperoleh nilai signifikan masing-masing sebesar $\mathrm{p}=0,000$ $(\mathrm{p}<0,05)$. Hasil ini menunjukkan bahwa adanya perbedaan yang signifikan antara kelompok bakteri uji dan kelompok konsentrasi dalam mempengaruhi diameter zona hambat.Kemudian dilanjutkan dengan uji Tukey Post Hoc untuk mengetahui kelompok konsentrasi mana dan kelompok bakteri mana mana saja yang memberikan perbedaan secara signifikan.

Berdasarkan uji TukeyPost Hoc perbedaan antara kelompok konsentrasi dilihat berdasarkan zona hambat. Hasil uji kontrol positif berbeda secara signifikan $\mathrm{p}=0,000 \quad(\mathrm{p}<0,005)$ dengan kontrol negatif, tetapi tidak berbeda secara signifikan $(p>0,005)$ dengan konsentrasi $10 \% \quad(p=0,477), \quad 20 \%$ $(\mathrm{p}=0,886)$ dan $30 \%(\mathrm{p}=0,086)$ terhadap diameter zona hambat. Hasil uji kontrol negatif memberikan hasil yang berbeda secara signifikan $\mathrm{p}=0,000 \quad(\mathrm{p}<0,005)$ dengan perlakuan kontrol positif, $10 \%$, $20 \%$ dan $30 \%$ dalam mempengaruhi diameter zona hambat. Hasil uji antara bakteri Branhamella catarrhalis berbeda signifikan $\mathrm{p}=0,000 \quad(\mathrm{p}<0,05)$ dengan Staphylococcus epidermidis dan Staphylococcus aureus terhadap diameter zona hambat. Respon yang berbeda dari tiga bakteri terhadap diameter zona hambat yang diperoleh bisa disebabkan oleh kecepatan difusi dari zat yang berbeda-beda, perbedaan respon dari bakteri itu sendiri (Dwijoseputro, 2005). Kemampuan ekstrak etanol biji pinang (Areca catechu L.) dalam menghambat pertumbuhan bakteri pada lidah membuktikan bahwa kandungan senyawa pada biji pinang yang diperoleh dari uji identifikasi berupa alkaloid, flavonoid dan terpenoid berpotensi sebagai antibakteri. Alkaloid memiliki kemampuan sebagai 
antibakteri, mekanisme penghambatan dengan cara mengganggu komponen penyusun peptidoglikan pada sel bakteri sehingga lapisan dinding sel tidak terbentuk secara utuh dan menyebabkan kematian sel tersebut. Senyawa terpenoid mempunyai kemampuan dalam menghambat bakteri, aktifitas antibakteri terpenoid diduga melibatkan pemecahan membran oleh komponenkomponen lipofilik. Senyawa flavonoid merupakan senyawa yang dapat menyebabkan penghambatan sintesis dinding sel bakteri. Oleh karena itu flavonoid merupakan komponen antibakteri yang potensial (Bobbarala, 2012)

\section{SIMPULAN}

Berdasarkan hasil penelitian dapat disimpulkan bahwa identifikasi bakteri yang diperoleh dari uji identifikasi berdasarkan warna bakteri yaitu Branhamella catarrhalis, Staphylococcus epidermidis dan Straphylococcus aureus. Ekstrak etanol biji pinang (Areca catechu L.) paling baik dalam menghambat pertumbuhan bakteri Staphylococcus epidermidis dan Staphylococcus aureus dibandingkan dengan Branhamella catarrhalis.

\section{SARAN}

Disarankan kepada peneliti selanjutnya untuk melakukan penelitian pengembangan produk obat kumur dari ekstrak biji pinang (Areca catechu L.) dan disarankan kepada masyarakat untuk lebih menjaga kebersihan mulut

\section{ACKNOWLEDGMENTS}

Terima kasih kepada Sekolah Tinggi Ilmu Farmasi Riau yang sudah memfasilitasi penelitian ini.

\section{DAFTAR PUSTAKA}

Aas, , Paster, Stokes, Olsen, dan Dewhirst, 2005, Defining the Normal Bacterial Flora of the Oral Cavity, Journal of Clinical Microbiology, 43(11): 5721-5732.

Afni, Said, dan Yuliet, 2015, Uji Aktivitas Antibakteri Pasta Gigi Ekstrak Biji Pinang (Areca catechu L.) terhadap Streptococcus mutans dan Staphylococcus aureus, Galenika Journal of Pharmacy, 1(1): 48-58.

Anggraeni, 2002, Pemanfaatan Ekstrak Selenium Pinang (Areca catechu L.) dengan fermentasi Acetobacter-saccharomyces sebagai Antiseptik Obat Kumur, Skripsi, Institut Pertanian Bogor: Bogor.

Depkes, 2013, Riset Kesehatan Dasar, Departemen Kesehatan Republik Indonesia: Jakarta.

Bobbarala, 2012, Antimicrobial Agents, Intech: Croatia.

Danser, Gomez, dan Weidjen, 2003, Tongue Coating and Tongue Brushing, International Journal of Dental Hygiene, 1(3): 151-158.

Dwijoseputro, , 2005, Dasar-Dasar Mikrobiologi. Djambatan: Jakarta. Harti, 2015, Mikrobiologi Kesehatan, CV. Andi Offset: Yogyakarta.

Jawetz, Melnick, dan Adelberg, 2014, Mikrobiologi Kedokteran, Edisi 27, Buku Kedokteran EGC: Jakarta.

Monea, Monea, Pop, dan Beresescu, 2014, Tongue Microflora And Periodontal Disease, European Scientific Journal, 10(36): 12- 
17Liu, Gao, Xia, dan Zhao, 2009 , Investigation of the sitespecific accumulation of catechin in the tea plant (Camellia sinensis (L.) O. Kuntze) via Vanillin- $\mathrm{HCl}$ Staining. J. Agric. Food Chem., 57, 10371-10376.

Pransiska, 2017, Pengaruh Pemberian Infusa Biji Pinang (Areca catechu L.) terhadap Jumlah Pertumbuhan Koloni Bakteri Pada Lidah dan Mukosa Rongga Mulut, Karya Tulis Ilmiah, Sekolah Tinggi Ilmu Farmasi Riau: Pekanbaru.

Pratiwi, 2008,Mikrobiologi Farmasi, Erlangga: Jakarta.

Radji, 2011, Buku Ajar Mikrobiologi Panduan Mahasiswa Farmasi dan Kedokteran, Buku Kedokteran EGC: Jakarta.

Shie, 2014, Uji Aktivitas Antibakteri Infusa Biji Pinang (Areca catechu Lin.) terhadap Streptococcus mutan, Skripsi, Fakultas Kedokteran Universitas Tanjungpura: Pontianak.

Spolsky, 2000, Epidemiology of Gingival and Periodontal Desease in Newman, M.G., Takei, H.H., Carranza, F.A. dan Klokkevold, P.R. Carranza's Clinical Periodontology, Saunders Elsevier: Missouri.

Taringan, 2012, Karies Gigi, Edisi 2, Buku Kedokteran EGC: Jakarta.

Wangko, 2013, Papila Lidah dan Kuncup Kecap, Journal Biomedik, 5(3): 40-42.

Yuliharsini, 2005, Kegunaan dan Efek Samping Obat Kumur Dalam Rongga Mulut, Skripsi, Fakultas Kedokteran Gigi Universitas Sumatera Utara: Medan.Liu, Gao, Xia, dan Zhao, 2009,
Investigation of the sitespecific accumulation of catechin in the tea plant (Camellia sinensis (L.) O. Kuntze) via Vanillin-HCl Staining. J. Agric. Food Chem., 57, 10371-10376. 